Case Report

\title{
Exertional Myopathy in a Juvenile Green Sea Turtle (Chelonia mydas) Entangled in a Large Mesh Gillnet
}

\author{
Brianne E. Phillips, ${ }^{1,2}$ Sarah A. Cannizzo, ${ }^{1,2}$ Matthew H. Godfrey, ${ }^{1,3}$ \\ Brian A. Stacy, ${ }^{4}$ and Craig A. Harms ${ }^{1,2}$ \\ ${ }^{1}$ Department of Clinical Sciences, College of Veterinary Medicine, North Carolina State University, 1060 William Moore Drive, \\ Raleigh, NC 27607, USA \\ ${ }^{2}$ Center for Marine Sciences and Technology, North Carolina State University, 303 College Circle, Morehead City, NC 28557, USA \\ ${ }^{3}$ North Carolina Wildlife Resources Commission, 1507 Ann Street, Beaufort, NC 28516, USA \\ ${ }^{4}$ National Marine Fisheries Service, National Oceanic and Atmospheric Administration, University of Florida, 2187 Mowry Road, \\ P.O. Box 110885, Gainesville, FL 32611, USA
}

Correspondence should be addressed to Craig A. Harms; craig_harms@ncsu.edu

Received 9 June 2015; Accepted 13 September 2015

Academic Editor: Luciano Espino López

Copyright (C) 2015 Brianne E. Phillips et al. This is an open access article distributed under the Creative Commons Attribution License, which permits unrestricted use, distribution, and reproduction in any medium, provided the original work is properly cited.

\begin{abstract}
A juvenile female green sea turtle (Chelonia mydas) was found entangled in a large mesh gillnet in Pamlico Sound, NC, and was weak upon presentation for treatment. Blood gas analysis revealed severe metabolic acidosis and hyperlactatemia. Plasma biochemistry analysis showed elevated aspartate aminotransferase and creatine kinase, marked hypercalcemia, hyperphosphatemia, and hyperkalemia. Death occurred within 24 hours of presentation despite treatment with intravenous and subcutaneous fluids and sodium bicarbonate. Necropsy revealed multifocal to diffuse pallor of the superficial and deep pectoral muscles. Mild, multifocal, and acute myofiber necrosis was identified by histopathological examination. While histological changes in the examined muscle were modest, the acid-base, mineral, and electrolyte abnormalities were sufficiently severe to contribute to this animal's mortality. Exertional myopathy in reptiles has not been well characterized. Sea turtle mortality resulting from forced submergence has been attributed to blood gas derangements and seawater aspiration; however, exertional myopathy may also be an important contributing factor. If possible, sea turtles subjected to incidental capture and entanglement that exhibit weakness or dull mentation should be clinically evaluated prior to release to minimize the risk of delayed mortality. Treatment with appropriate fluid therapy and supportive care may mitigate the effects of exertional myopathy in some cases.
\end{abstract}

\section{Introduction}

The green sea turtle (Chelonia mydas) is one of five sea turtle species that frequents the coastal waters of North Carolina, USA [1]. Sea turtle stranding cases in this region are attributed to watercraft-related trauma, hypothermic-stunning, commercial and recreational fishing incidental captures, and disease. Incidental captures in fishing gear comprise a large part of North Carolina sea turtle stranding cases [2]. In 2014, there were 255 green sea turtle stranding cases reported in North Carolina and 22\% (57/255) were attributed to fisheries interactions [3]. During the North Carolina gillnet fishing season from 1 June to 30 November 2014, incidental captures in large mesh gillnets resulted in 307 nonlethal and 153 lethal interactions with green sea turtles, based on calculations from observer reports and fishing effort $[4,5]$.

The effect of fishing gear related capture and entanglement on sea turtles is an important area of study for the purposes of mitigating mortality and injury, as well as improving the medical assessment and treatment of these animals. United States shrimp trawlers are required to use Turtle Excluder Devices (TEDs), a grid installed in the trawl net that allows larger animals, particularly sea turtles, to be ejected from the net and thereby minimize incidental captures. In shrimp trawls without TEDs, longer trawl times result in higher sea turtle mortality rates due to the increased duration 
of forced submergence [6]. The mandatory implementation and use of TEDs were associated with decreased sea turtle stranding cases and reduced rate of population decline [7].

The physiologic effects of voluntary and forced submergence on sea turtles have been examined in both field and laboratory settings. Voluntary submergence is mostly aerobic, with minimal acid-base changes during short dive periods [8]. Prolonged voluntary dives are associated with respiratory acidosis and anaerobic metabolism [9]. Forced submergence due to fishery gear interactions, most notably trawl nets, may result in prolonged periods of hypoxia, seawater aspiration, pulmonary edema, and airway edema and hemorrhage [10]. Kemp's ridley sea turtles (Lepidochelys kempii) placed in trawl nets exhibited a metabolic acidosis with a 6-fold lactate increase in posttrawl blood samples [11]. Loggerhead sea turtles (Caretta caretta) subjected to forced submergence had a respiratory acidosis with hyperlactatemia [12]. As compared to loggerhead sea turtles captured in pound nets, which allow turtles to surface for respiration, trawl-captured loggerhead sea turtles have greater acid-base and lactate derangements [13]. In addition, forced submergence was recently associated with both intra- and extravascular gas embolism in loggerhead sea turtles [14]. That study utilized a combination of clinical pathology, gross necropsy, advanced imaging, and histopathology to demonstrate this clinical scenario in loggerhead sea turtles.

Gillnets are fixed nets used in shallow waters to entrap target teleost species. Interactions between sea turtles and estuarine large mesh gillnets with extended soak periods resulted in high sea turtle mortality rates in North Carolina in the late 1990s and subsequently led to restricted time and area fishing closures in the state [15]. Large mesh net capture of Kemp's ridley sea turtles resulted in high norepinephrine and epinephrine values in postcapture blood samples, suggesting capture-induced neuroendocrine stress response [16]. Greater duration of gillnet entanglement was associated with significant increases in plasma lactate, lactate dehydrogenase $(\mathrm{LDH})$, creatine kinase $(\mathrm{CK})$, and phosphorous levels in green sea turtles [17]. These clinical pathology changes were suspected to be due to the exertion and muscle damage associated with entanglement, but the study lacked supporting evidence from blood gas analysis, gross postmortem examination, and histopathology.

Exertional myopathy, or capture myopathy, is a multifactorial, noninfectious metabolic disease that is well described in mammalian and avian species. This disease is characterized by metabolic acidosis, muscle necrosis, and myoglobinuria [22]. Exertional myopathy can manifest in various clinical presentations and result in a range of clinical pathology changes and histopathologic lesions. While skeletal muscle and renal tissue are predominantly affected, exertional myopathy can also lead to widespread tissue necrosis throughout many organ systems [23]. Severe cases are associated with a poor prognosis. Exertional myopathy in reptile species and other poikilotherms is poorly characterized [24]. Here we present a case of exertional myopathy in a green sea turtle resulting from entanglement in a large mesh gillnet. Diagnostics included blood gas analysis, plasma biochemistry, gross necropsy, and histopathologic examination, which collectively are not typically available or presented in instances of sea turtle forced submergence and fishery interaction.

\section{Case Presentation}

A $4.65 \mathrm{~kg}$ juvenile female green sea turtle (straight carapace length $33.2 \mathrm{~cm}$, curved carapace length $35.1 \mathrm{~cm}$ ) was found entangled in a large mesh gillnet (stretched mesh length greater than $12.7 \mathrm{~cm}$ ) on 3 October 2014 in Pamlico Sound, NC (latitude $35^{\circ} 04.480^{\prime}$ and longitude $76^{\circ} 04.897^{\prime}$ ). Marine Patrol officers observed the entanglement and reported the severely weak animal to the North Carolina Wildlife Resources Commission. The turtle arrived within approximately 1-2 hours at the North Carolina State University Center for Marine Science and Technology (NCSU CMAST, Morehead City, NC) for further evaluation and care.

On presentation the turtle was dull but responsive to tactile stimulation. It was quadriparetic and did not attempt to move its flippers when handled. A small amount of frank blood was present at the medial canthus of the right eye and sand adhered to both corneas. The turtle was in adequate body condition with no prominent skeletal features. Live barnacles were present, occupying less than $10 \%$ of the carapace and plastron. Approximately 10-15 leeches were present on the ventral cervical region and ventral plastron. Superficial abrasions were present on the trailing edge of the right front flipper and ventral aspect of the mandible.

Initial heart rate was 30/min (Pocket-Dop 3 Doppler flow probe, CareFusion, Middleton, WI) and cloacal temperature was $20^{\circ} \mathrm{C}$ (Barnant Thermocouple Thermometer, Barnant Company, Barrington, IL). Respiratory rate was $2-4 / \mathrm{min}$ and no abnormal respiratory sounds were heard. Venipuncture was performed at the left dorsal cervical sinus and the blood sample was evaluated for packed cell volume (PCV) by centrifugation, total solids (TS) by refractometry, and blood gas analysis using an iSTAT point of care analyzer with a CG4+ cartridge (Abaxis, Union City, CA) (Tables 1 and 2). Results revealed a PCV/TS of $40 \% / 4.0 \mathrm{~g} / \mathrm{dL}$, a severe metabolic acidosis, and severe hyperlactatemia. Based on history, physical examination, and severity of blood gas derangements, exertional myopathy was suspected. The turtle was treated with intravenous fluids $(5 \mathrm{~mL} / \mathrm{kg}$ of $50 \%$ LRS and 50\% 0.9\% NaCl; Abbott Laboratories, North Chicago, IL) injected over 3 minutes in the left dorsal cervical sinus and subcutaneous fluids $(10 \mathrm{~mL} / \mathrm{kg} \quad 0.9 \% \mathrm{NaCl}, 5 \mathrm{~mL} / \mathrm{kg}$ lactated Ringer's solution) administered over the left and right shoulders. Ceftazidime $20 \mathrm{mg} / \mathrm{kg}$ IM (Covis Pharmaceuticals, Inc., Cary, NC) was also administered to the turtle in the right pectoral muscle, in case of aspiration.

Recheck examination was performed approximately 4 hours after initial presentation. The turtle remained weak and heart rate was $4-12 / \mathrm{min}$. Venipuncture was repeated and the blood sample was evaluated using iSTAT CG4+ and CG8+ cartridges and the VetScan VS2 point of care analyzer with an Avian Reptilian Profile Plus reagent rotor (Abaxis, Union City, CA). Clinical pathology results revealed a persistent but slightly improved severe metabolic acidosis (Tables 1 and 2). 
TABLE 1: Blood gas results from a large mesh gillnet entangled green sea turtle (Chelonia mydas). Values marked with "-" were not obtained. Initial sample was obtained at presentation and the recheck sample was performed approximately 4 hours later. Blood gas analysis performed using iSTAT CG4+ and CG8+ cartridges. Range values based on published iSTAT results of free-ranging juvenile green sea turtles [18, 19]. Temperature correction (TC) was performed at the turtle's cloacal temperature $\left(20.0^{\circ} \mathrm{C}\right)$ for $\mathrm{pH}, \mathrm{pCO}_{2}, \mathrm{pO}_{2}$, and ionized calcium based on formulas presented in Anderson et al. 2011 [18].

\begin{tabular}{lccc}
\hline Analyte & Initial (CG4+) & Recheck (CG4+; CG8+) & Range \\
\hline pH at $37^{\circ} \mathrm{C}$ & 6.703 & 6.751 & $7.187-7.516^{\mathrm{a}}$ \\
$\mathrm{pH}$ TC & 6.896 & 6.944 & $7.273-7.626^{\mathrm{b}}$ \\
Partial pressure carbon dioxide $(\mathrm{mmHg})$ at $37^{\circ} \mathrm{C}$ & 52.2 & 69.7 & $59.1-84.3^{\mathrm{c}}$ \\
Partial pressure carbon dioxide $(\mathrm{mmHg}) \mathrm{TC}$ & 24.4 & 33.1 & $32.4-65.4^{\mathrm{b}}$ \\
Partial pressure oxygen $(\mathrm{mmHg})$ at $37^{\circ} \mathrm{C}$ & 73 & 28 & $38-53^{\mathrm{a}}$ \\
Partial pressure oxygen $(\mathrm{mmHg}) \mathrm{TC}$ & 58 & 22 & $38-53^{\mathrm{a}}$ \\
Bicarbonate $(\mathrm{mmol} / \mathrm{L})$ & 6.5 & 9.7 & $14-32^{\mathrm{b}}$ \\
Total carbon dioxide $(\mathrm{mmol} / \mathrm{L})$ & 8 & 12 & $35.6-58.2^{\mathrm{b}}$ \\
Lactate $(\mathrm{mmol} / \mathrm{L})$ & $>20.0$ & $>20.0$ & $24-43^{\mathrm{c}}$ \\
Sodium $(\mathrm{mmol} / \mathrm{L})$ & - & 137 & $0.8-8.73^{\mathrm{b}}$ \\
Potassium $(\mathrm{mmol} / \mathrm{L})$ & - & $>9.0$ & $143-153^{\mathrm{b}}$ \\
Ionized calcium $(\mathrm{mmol} / \mathrm{L})$ & - & 1.15 & $2.7-4.3^{\mathrm{b}}$ \\
Glucose $(\mathrm{mg} / \mathrm{dL})$ & - & 137 & $0.87-1.24^{\mathrm{a}}$ \\
\hline
\end{tabular}

${ }^{a}$ Anderson et al. 2011 [18], juvenile free-ranging green sea turtles; $n=8$.

${ }^{\mathrm{b}}$ Lewbart et al. 2014 [19], free-ranging green sea turtles; $n=12$.

${ }^{\mathrm{c}} \mathrm{CAH}$ unpublished data, study animals in Anderson et al. 2011 [18].

Also noted were a moderately elevated aspartate aminotransferase (AST) and severe hypercalcemia, hyperkalemia, hyperphosphatemia, and hyperlactatemia. The CK and potassium did not read on the VetScan but were suspected to be elevated out of instrument range, and hyperkalemia was confirmed with the iSTAT analyzer. The VetScan Avian Reptile Profile Plus CK and potassium instrument ranges are $5-14,000 \mathrm{U} / \mathrm{L}$ and $1.5-8.5 \mathrm{mmol} / \mathrm{L}$, respectively [21]. The iSTAT sodium value was decreased but was suspected to be a spurious result because the VetScan sodium value was within reported green sea turtle sodium ranges $[18,20]$. The turtle was treated with additional subcutaneous fluids $(10 \mathrm{~mL} / \mathrm{kg}$ $0.9 \% \mathrm{NaCl}$ ) combined with sodium bicarbonate $0.5 \mathrm{mEq} / \mathrm{kg}$ (Hospira, Inc., Lake Forest, IL) split between the shoulders and prefemoral regions.

The turtle was found dead at 08:00 on 4 October 2014 and death was confirmed via Doppler flow probe. A necropsy was performed and tissue samples were saved for histopathology in $10 \%$ neutral buffered formalin. The turtle had adequate musculature and fat stores. Multifocal to diffuse regions of muscle pallor were observed in the superficial and deep pectoral muscles (Figure 1). A small amount of foam was found in the distal main stem bronchi. No fluid or foreign material was present in the respiratory tract. The liver appeared mottled and the spleen bulged on cut section. The entire gastrointestinal tract was filled with digesta, mostly sea grass. The mesenteric vessels and serosal vessels on the liver were prominent. The urinary bladder was devoid of urine. There were no gross lesions to either kidney.

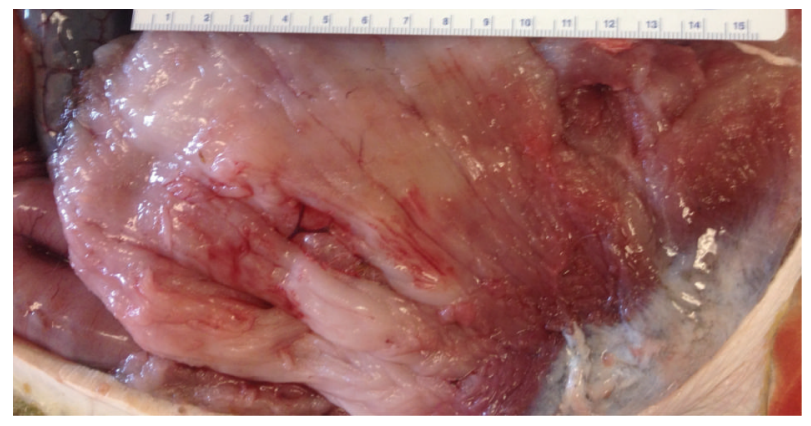

FIGURE 1: The left superficial and deep pectoral muscles of a green sea turtle (Chelonia mydas). Multifocal regions of pallor are present.

Histopathology of the pectoral muscles revealed mild, multifocal, acute myofiber necrosis characterized by loss of cross striations, hypercontraction, and segmental disruption of the sarcoplasm. Density of affected myofibers was variable within sections. Some muscle fascicles had rare or no affected myofibers and a few were more diffusely affected (Figure 2). There were no histopathological changes observed in the kidneys. All additional findings were relatively minor and considered incidental, including endarteritis with medial hypertrophy affecting small pulmonary arteries and minimal, chronic endocarditis. These cardiovascular lesions were consistent with response to spirorchiid trematode infection, 
TABLE 2: Plasma chemistry and hematology results from a large mesh gillnet entangled green sea turtle (Chelonia mydas). PCV/TS was performed at initial presentation. Plasma chemistry performed using the VetScan Avian Reptilian Profile Plus reagent rotor at 4 hours after presentation. Range values based on published freeranging juvenile green sea turtles from North Carolina caught via pound nets [18] and from the Bahamas during diving [20]. Both studies utilized a benchtop chemistry analyzer at diagnostic laboratories for plasma chemistry analysis. Analytes marked with an $*$ were outside the instrument range. The VetScan Avian Reptile Profile Plus CK and potassium instrument ranges are 5-14,000 U/L and $1.5-8.5 \mathrm{mmol} / \mathrm{L}$, respectively [21]. The CK range reported by Anderson et al. 2011 [18] was likely affected by the capture technique, which included pound net capture for undetermined time and transport on boat prior to blood sample collection.

\begin{tabular}{lcc}
\hline Analyte & Value & Range \\
\hline Packed cell volume $(\%)$ & 40 & $30-39^{\mathrm{a}} ; 26.4-42.0^{\mathrm{b}}$ \\
Total solids $(\mathrm{g} / \mathrm{dL})$ & 4.0 & $2.5-4.4^{\mathrm{a}}$ \\
Total protein $(\mathrm{g} / \mathrm{dL})$ & 3.8 & $2.6-3.5^{\mathrm{a}} ; 2.6-6.9^{\mathrm{b}}$ \\
Albumin $(\mathrm{g} / \mathrm{dL})$ & 1.3 & $1.1-1.6^{\mathrm{a}} ; 0.6-2.1^{\mathrm{b}}$ \\
Globulin $(\mathrm{g} / \mathrm{dL})$ & 2.5 & $1.3-2.1^{\mathrm{a}} ; 1.9-5.2^{\mathrm{b}}$ \\
Aspartate aminotransferase (U/L) & 865 & $134-497^{\mathrm{a}} ; 31-389^{\mathrm{b}}$ \\
Bile acids $(\mu \mathrm{mol} / \mathrm{L})$ & 47 & $($ No reference available) \\
Creatine kinase $(\mathrm{U} / \mathrm{L})$ & $*$ & $841-42,586^{\mathrm{a}}$ \\
Uric acid $(\mathrm{mg} / \mathrm{dL})$ & 5.7 & $0.7-2.7^{\mathrm{a}} ; 0.5-3.5^{\mathrm{b}}$ \\
Glucose $(\mathrm{mg} / \mathrm{dL})$ & 163 & $97-244^{\mathrm{a}} ; 87-167^{\mathrm{b}}$ \\
Calcium $(\mathrm{mg} / \mathrm{dL})$ & 17.0 & $6.3-8.8^{\mathrm{a}} ; 1.6-12.2^{\mathrm{b}}$ \\
Phosphorous $(\mathrm{mg} / \mathrm{dL})$ & 18.0 & $4.4-9.0^{\mathrm{a}} ; 3.8-10.9^{\mathrm{b}}$ \\
Sodium $(\mathrm{mmol} / \mathrm{L})$ & 152 & $152-159^{\mathrm{a}} ; 157-183^{\mathrm{b}}$ \\
Potassium $(\mathrm{mmol} / \mathrm{L})$ & $*$ & $3.6-6.4^{\mathrm{a}} ; 4.1-6.9^{\mathrm{b}}$ \\
\hline
\end{tabular}

${ }^{a}$ Anderson et al. 2011 [18], juvenile free-ranging green sea turtles; $n=12$.

${ }^{\mathrm{b}}$ Bolten and Bjorndal 1992 [20], juvenile free-ranging green sea turtles; $n=$ 100 .

although spirorchiidiasis was not confirmed by gross or histologic examination $[25,26]$. Minimal eosinophilic gastritis and enteric granulocytic infiltrates were also noted and attributed to alimentary endoparasites.

\section{Discussion}

This case documents histopathology and severe clinical pathology abnormalities in a gillnet-entangled juvenile green sea turtle consistent with exertional myopathy. Exertional myopathy is characterized by various degrees of myocyte necrosis on histopathology, which occurs secondary to increased anaerobic metabolism and lactic acid production [22]. In this case, only mild myofiber necrosis was documented, but the severity of muscle lesions was variable within sections examined by histology. Additional affected areas and more severe lesions are possible in other muscles that were not evaluated. It also suggests that the skeletal muscle lesions do not necessarily correlate with the severity of the clinical pathologic changes or, alternatively, that mild necrosis of a large amount of muscle tissue may have similar effects as severe necrosis in a small muscle mass.

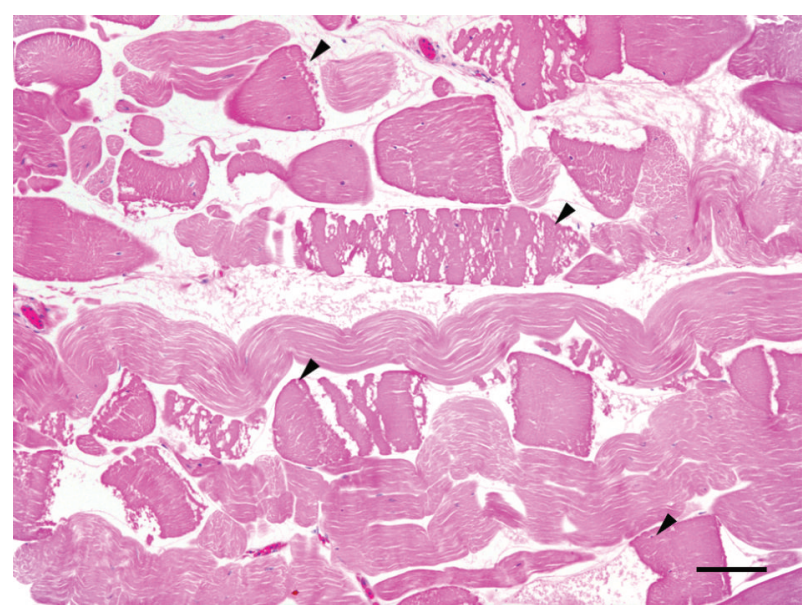

FIgure 2: Pectoral muscle of a green turtle (Chelonia mydas) incidentally captured in a large mesh gillnet. There is multifocal necrosis of individual myofibers that is characterized by hypercontraction, loss of cross striations, and segmental disruption of the sarcoplasm (black arrowheads). Hematoxylin and eosin. Scale $=100 \mu \mathrm{m}$.

Metabolic acidosis is one of the predominant clinical pathology findings associated with exertional myopathy. Acidosis occurs as a result of decreased mitochondrial activity in skeletal muscle and initiation of anaerobic glycolysis that leads to lactic acid production [23]. Capture-related lactic acidosis has previously been documented in several capture effects and forced submergence studies in sea turtles. The severity of acidosis in this case $\left(\mathrm{pH}_{\mathrm{at} 37^{\circ} \mathrm{C}} 6.703 ; \mathrm{pH}_{\mathrm{TC}} 6.896\right)$ exceeded the acidosis reported in forced submergence, trawland pound net-capture studies ( $\mathrm{pH}$ range of 6.9-7.3) [1113]. The decreased bicarbonate ion and total carbon dioxide are further consistent with metabolic acidosis. The lactate in this case exceeded the instrument range $(>20 \mathrm{mmol} / \mathrm{L})$. The hyperlactatemia documented here was comparable to or in excess of the lactate concentrations reported in sea turtle forced submergence and capture effects studies, and the blood gas values suggest that exertional myopathy in the green sea turtle can result in extreme acidosis.

Exertional myopathy is often associated with increased plasma AST, CK, and $\mathrm{LDH}$ activities in mammals due to myocyte injury [23]. This case included elevations in both AST and CK, and LDH was not evaluated. Multiple tissues express AST activity in loggerhead sea turtles, including cardiac and skeletal muscle [27]. Skeletal muscle damage likely resulted in the moderate elevation in AST and the suspected $\mathrm{CK}$ increase seen in this case. Similar enzyme elevations were documented in the evaluation of incidental capture effects on Kemp's ridley and green sea turtles. A positive association with gillnet entanglement time and elevations in plasma LDH and CK was reported in both species [17]. Other capture effects studies have lacked tissue enzyme evaluation as well as histological confirmation of muscle injury, which were documented in the green turtle of this report [17, 28].

The cellular degradation that occurs during exertional myopathy leads to decreased sodium-potassium transport across cell membranes as well as cell rupture [23]. Subsequent 
increases in extracellular potassium concentrations result, as was seen in the current green sea turtle case. Significant increases in potassium values have been associated with capture stress and forced submergence in sea turtles. Elevated potassium occurred in a single gillnet-associated mortality following release, but insufficient data were available to correlate electrolyte disturbances with mortality, and fresh postmortem examination was not possible [28]. The degree of hyperkalemia was higher in the current case $(>9.0 \mathrm{mEq} / \mathrm{L})$ with demonstrated exertional myopathy as compared to reported hyperkalemia secondary to forced submergence and capture effects studies in sea turtles $[12,16,17]$. There was also a marked elevation in phosphorus in this case as compared to values reported in free-ranging green sea turtles $[18,20]$. Elevations in phosphorous have been associated with severe tissue trauma secondary to cell leakage in reptiles as well as renal dysfunction [29]. The hyperphosphatemia demonstrated in this exertional myopathy case in combination with elevations of muscle specific enzymes was also documented in gillnet-captured green and Kemp's ridley sea turtles with similar enzyme elevations [17].

This case identified elevations in total calcium and uric acid, which were suspected to be due to acutely decreased renal perfusion. Prolonged sympathetic stimulation, which occurs during exertional myopathy, leads to systemic hypotension and results in decreased cardiac output and blood flow to vital organs including the kidneys [23]. While there were no gross or histopathologic renal lesions and a urine sample was not available postmortem for evaluation, a prolonged decrease in renal perfusion likely decreased renal function and manifested clinically by marked elevations in total calcium and uric acid. Other causes of increased total calcium and uric acid in reptiles including vitellogenesis in reproductively mature females, osteolytic bone disease, granulomatous disease, hyperparathyroidism, gout, and postprandial high protein meal were excluded based on plasma chemistry, gross, and histopathologic examination [29]. Statistically insignificant trends in plasma calcium elevations in comparison to reference ranges were reported following gillnet capture in both green and Kemp's ridley sea turtles [17].

Decompression sickness has recently been documented in gillnet- and trawl-captured loggerhead sea turtles [14]. In these cases, turtles exhibited progressive neurologic signs and positive buoyancy, and widespread intravascular gas embolism was documented using radiography, ultrasonography, and computed tomography. Postmortem and histologic examination typically revealed gas bubbles in the right atrium, lungs, and vasculature. Both duration and depth of capture were associated with gas embolism formation and clinical signs manifested at a minimum capture depth of $10.5 \mathrm{~m}$ [14]. Depths in the region of the Pamlico Sound gillnet fishery range between 0 and $2 \mathrm{~m}$. In the case described herein, there were no gas bubbles observed during necropsy or by histology; therefore, there was no evidence that decompression sickness contributed to mortality.

Treatment of exertional myopathy requires aggressive fluid therapy and supportive care. Successful rehabilitation of a rhea with exertional myopathy included fluid therapy, supplemental feedings, methocarbamol, and anxiolytics [30].
Three wild greater sandhill cranes (Grus canadensis tabida) with exertional myopathy were successfully released following intensive treatment with fluids, nutritional support, and physical therapy [31]. The empirical treatments, dexamethasone, vitamin E, and selenium, have been administered in cases of exertional myopathy, but therapeutic efficacy has not been evaluated in a controlled manner. Extensive treatment lasting several weeks may be required. Sea turtles markedly affected by exertional myopathy may require housing in a rehabilitation center that could provide daily care and observation. Mammalian and avian cases of exertional myopathy are typically associated with a poor prognosis [22].

Mortality following capture in fishing gear has been attributed to blood gas derangements and seawater aspiration resulting from forced submergence, associated trauma, and decompression sickness. As demonstrated in this case, exertional myopathy is an additional consideration. It may be distinguished by the occurrence of a more severe acidosis, hyperlactatemia, severe elevations in potassium, phosphorous, and $\mathrm{CK}$, as well as concurrent myocyte necrosis on histopathology. Blood chemistry derangements can be severe despite seemingly minor histological lesions in the skeletal muscle, the significance of which may be underappreciated in suspected bycatch animals that are found dead as stranding cases and lack clinical assessment or circumstantial information. Prompt and thorough evaluation of sea turtle entanglement cases exhibiting weakness and dull mentation is recommended if possible. Cases exhibiting these clinical signs and with clinical pathology abnormalities consistent with exertional myopathy should be treated aggressively with fluid therapy and supportive care. Immediate release of sea turtles involved in fishery gear entanglements that exhibit overt clinical signs may result in delayed, unobserved mortality due to the physiologic effects, including those related to exertional myopathy.

\section{Conflict of Interests}

The authors declare that there is no conflict of interests regarding the publication of this paper.

\section{Acknowledgments}

The authors thank Heather Broadhurst and Emily Christiansen for their technical assistance during this case.

\section{References}

[1] S. P. Epperly, J. Braun, and A. Veishlow, "Sea turtles in North Carolina waters," Conservation Biology, vol. 9, no. 2, pp. 384394, 1995.

[2] C. M. McClellan, A. J. Read, W. M. Cluse, and M. H. Godfrey, "Conservation in a complex management environment: the bycatch of sea turtles in North Carolina's commercial fisheries," Marine Policy, vol. 35, no. 2, pp. 241-248, 2011.

[3] North Carolina Wildlife Resources Commissions, Seaturtle.org, 2015, http://www.seaturtle.org/strand/summary/. 
[4] J. Boyd, "Fall 2014 seasonal progress report," Incidental Take Permit 16230, North Carolina Division of Marine Fisheries, Morehead City, NC, USA, 2014.

[5] J. Boyd, "Summer 2014 seasonal progress report," Incidental Take Permit 16230, North Carolina Division of Marine Fisheries, 2014.

[6] C. R. Sasso and S. P. Epperly, "Seasonal sea turtle mortality risk from forced submergence in bottom trawls," Fisheries Research, vol. 81, no. 1, pp. 86-88, 2006.

[7] L. B. Crowder, S. R. Hopkins-Murphy, and J. A. Royle, "Effects of turtle excluder devices (TEDs) on loggerhead sea turtle strandings with implications for conservation," Copeia, no. 4, pp. 773-779, 1995.

[8] M. E. Lutcavage and P. L. Lutz, "Voluntary diving metabolism and ventilation in the loggerhead sea turtle," Journal of Experimental Marine Biology and Ecology, vol. 147, no. 2, pp. 287-296, 1991.

[9] P. L. Lutz and T. B. Bentley, "Respiratory physiology of diving in the sea turtle," Copeia, vol. 1985, no. 3, pp. 671-679, 1985.

[10] T. M. Work and G. H. Balazs, "Pathology and distribution of sea turtles landed as bycatch in the hawaii-based north pacific pelagic longline fishery," Journal of Wildlife Diseases, vol. 46, no. 2, pp. 422-432, 2010.

[11] E. K. Stabenau, T. A. Heming, and J. F. Mitchell, "Respiratory, acid-base and ionic status of kemp's ridley sea turtles (Lepidochelys kempi) subjected to trawling," Comparative Biochemistry and Physiology A, vol. 99, no. 1-2, pp. 107-111, 1991.

[12] E. K. Stabenau and K. R. N. Vietti, “The physiological effects of multiple forced submergences in loggerhead sea turtles (Caretta caretta)," Fishery Bulletin, vol. 101, no. 4, pp. 889-899, 2003.

[13] C. A. Harms, K. M. Mallo, P. M. Ross, and A. Segars, "Venous blood gases and lactates of wild loggerhead sea turtles (Caretta caretta) following two capture techniques," Journal of Wildlife Diseases, vol. 39, no. 2, pp. 366-374, 2003.

[14] D. García-Párraga, J. L. Crespo-Picazo, Y. Bernaldo de Quirós et al., "Decompression sickness ('the bends') in sea turtles," Diseases of Aquatic Organisms, vol. 111, no. 3, pp. 191-205, 2014.

[15] B. L. Byrd, A. A. Hohn, and M. H. Godfrey, "Emerging fisheries, emerging fishery interactions with sea turtles: a case study of the large-mesh gillnet fishery for flounder in Pamlico Sound, North Carolina, USA," Marine Policy, vol. 35, no. 3, pp. 271-285, 2011.

[16] L. A. Hoopes, A. M. Landry Jr., and E. K. Stabenau, "Physiological effects of capturing Kemp's ridley sea turtles, Lepidochelys kempii, in entanglement nets," Canadian Journal of Zoology, vol. 78, no. 11, pp. 1941-1947, 2000.

[17] J. E. Snoddy, M. Landon, G. Blanvillain, and A. Southwood, "Blood biochemistry of sea turtles captured in gillnets in the lower cape fear river, North Carolina, USA," Journal of Wildlife Management, vol. 73, no. 8, pp. 1394-1401, 2009.

[18] E. T. Anderson, C. A. Harms, E. M. Stringer, and W. M. Cluse, "Evaluation of hematology and serum biochemistry of coldstunned green sea turtles (Chelonia mydas) in North Carolina, USA," Journal of Zoo and Wildlife Medicine, vol. 42, no. 2, pp. 247-255, 2011.

[19] G. A. Lewbart, M. Hirschfeld, J. Denkinger et al., "Blood gases, biochemistry, and hematology of galapagos green turtles (Chelonia mydas)," PLoS ONE, vol. 9, no. 5, Article ID e96487, 2014.
[20] A. B. Bolten and K. A. Bjorndal, "Blood profiles for a wild population of green turtles (Chelonia mydas) in the southern Bahamas: size-specific and sex-specific relationships," Journal of Wildlife Diseases, vol. 28, no. 3, pp. 407-413, 1992.

[21] Abaxis, "VetScan Avian Reptilian Profile Plus package insert," 2007, http://www.abaxis.com/pdf/Avian-Reptilian\%20Profile $\% 20$ Plus.pdf.

[22] J. Patterson, "Capture myopathy," in Zoo Animal and Wildlife Immobilization, G. West, D. Heard, and N. Chalkett, Eds., pp. 171-179, Wiley-Blackwell, 2nd edition, 2014.

[23] T. R. Spraker, "Stress and capture myopathy in artiodactyls," in Zoo and Wild Animal Medicine, Current Therapy, M. E. Fowler, Ed., pp. 481-488, W.B. Saunders Company, Philadelphia, Pa, USA, 3rd edition, 1993.

[24] E. S. Williams and E. T. Thorne, "Exertional myopathy (capture myopathy)," in Noninfectious Diseases of Wildlife, A. Fairbrother, L. N. Locke, and G. L. Hoff, Eds., pp. 181-193, Iowa State University Press, Ames, Iowa, USA, 2nd edition, 1996.

[25] A. N. Gordon, W. R. Kelly, and T. H. Cribb, "Lesions caused by cardiovascular flukes (Digenea: Spirorchidae) in stranded green turtles (Chelonia mydas)," Veterinary Pathology, vol. 35, no. 1, pp. 21-30, 1998.

[26] M. Santoro, J. A. Morales, and B. Rodríguez-Ortíz, "Spirorchiidiosis (Digenea: Spirorchiidae) and lesions associated with parasites in Caribbean green turtles (Chelonia mydas)," Veterinary Record, vol. 161, no. 14, pp. 482-486, 2007.

[27] E. T. Anderson, V. L. Socha, J. Gardner, L. Byrd, and C. A. Manire, "Tissue enzyme activities in the loggerhead sea turtle (Caretta caretta)," Journal of Zoo and Wildlife Medicine, vol. 44, no. 1, pp. 62-69, 2013.

[28] J. E. Snoddy and A. S. Williard, "Movements and post-release mortality of juvenile sea turtles released from gillnets in the lower Cape Fear River, North Carolina, USA," Endangered Species Research, vol. 12, no. 3, pp. 235-247, 2010.

[29] T. W. Campbell, "Clinical pathology," in Current Therapy in Reptile Medicine and Surgery, D. R. Mader and S. J. Divers, Eds., pp. 70-92, Saunders, St. Louis, Mo, USA, 2014.

[30] K. M. Smith, S. Murray, and C. Sanchez, "Successful treatment of suspected exertional myopathy in a rhea (Rhea americana)," Journal of Zoo and Wildlife Medicine, vol. 36, no. 2, pp. 316-320, 2005.

[31] N. K. Businga, J. Langenberg, and L. Carlson, "Successful treatment of capture myopathy in three wild greater sandhill cranes (Grus canadensis tabida)," Journal of Avian Medicine and Surgery, vol. 21, no. 4, pp. 294-298, 2007. 

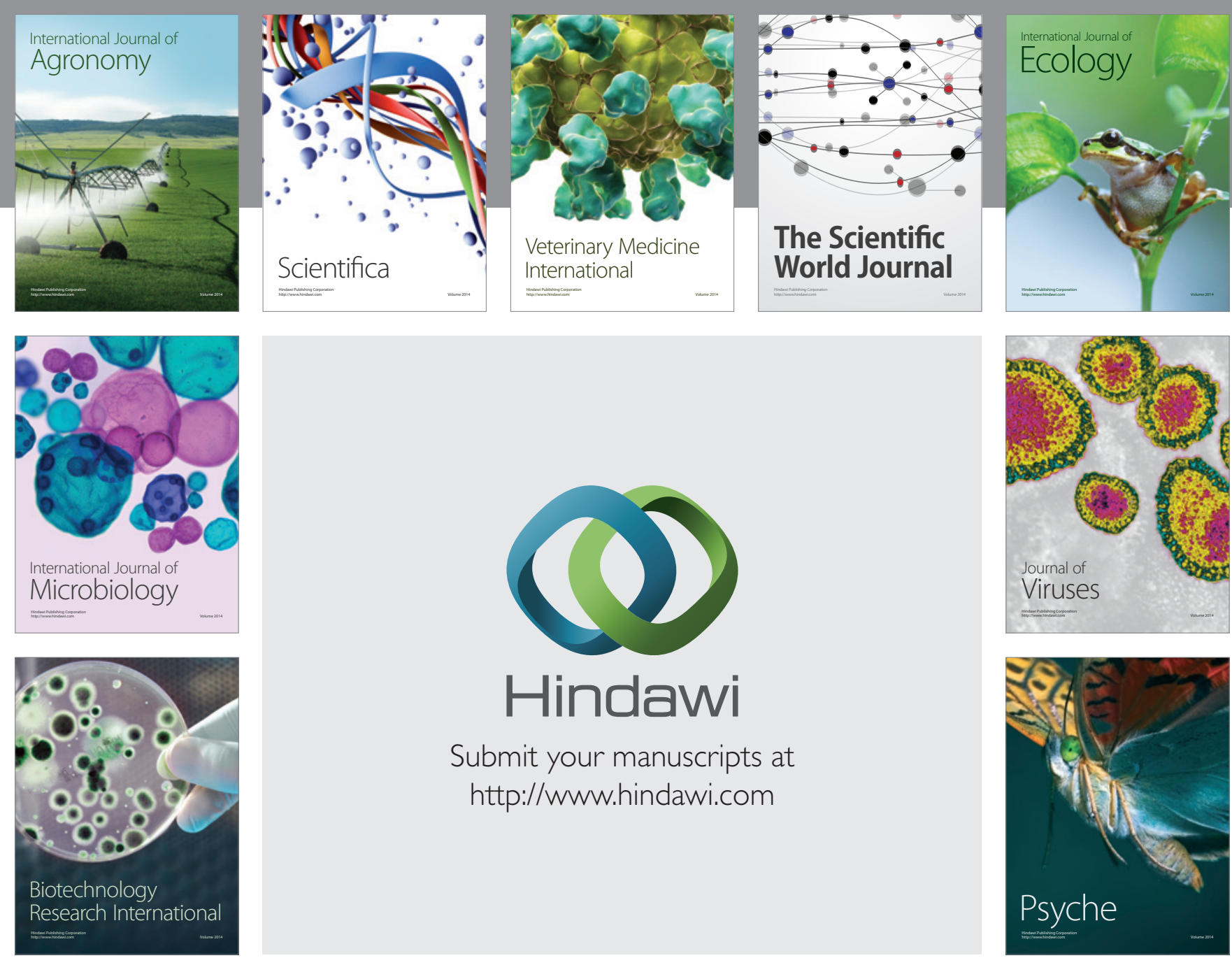

Submit your manuscripts at http://www.hindawi.com
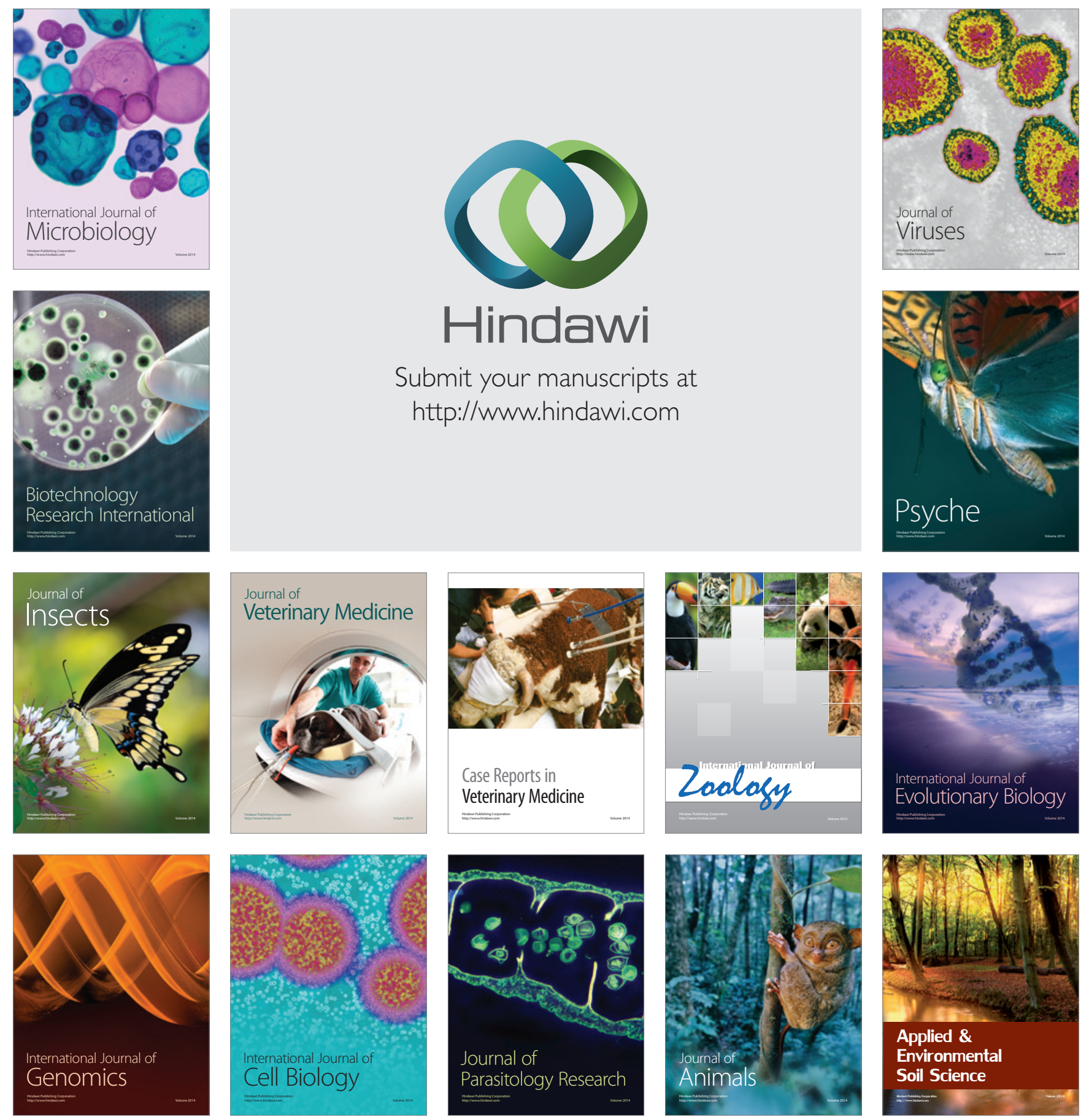